\author{
Маја Радонић \\ Факултет за културу и медије \\ Београд \\ majar@yandex.ru
}

821.163.41-1.09 Марковић М.
https://doi.org/10.18485/ai pesnikinje.2018.ch8

\title{
ПОЕЗИЈА ЗА ЖИВЕ И МРТВЕ
}

(О песмама Милене Марковић)

Поезија савремене драмске списатељице, сценаристе и песникиње Милене Марковић (1974), сразмерно је мало заступљена међу проучаваоцима њеног дела у односу на драмски опус. Међутим, овај модеран и снажан песнички глас новије српске поезије, доноси на први поглед скривену, али суштински аутентичну везу са сопственом песничком традицијом. Овај рад указује на специфичности и самосовојност песничке поетике Милене Марковић, којом песникиња наративних исказа, исповедног тона и свакодневног језика, лишеног интелектуализовања, постиже високу лиричност и убедљивост истинске поезије.

Къучне речи: Милена Марковић, поезија, поетика, наративност, традиција.

Милена Марковић (1974), песникиња, драмски писац и сценариста, објавила је шест песничких збирки: Пас који је йојо сунце, Истиина има йеране, Црна кашика, Питичје око на йараби, Пре неі̄о шито све йочне gа се вриии и Песме за живе и мритве, а сабране песме у два тома до сада су објављене у три издања 2012, 2013. и 2016. године. Већ од успеха дипломске представе Павильни или куgа ияем одакле долазим и итиа има за вечеру, Марковићева је ушла у канон српских савреме- 
них драмских писаца постмодерне, а статус једног од најзначајнијих савремених драмских аутора потврдиле су и драме Бої нас йойлеgао - Шине, Шума блисииа, Броg за луйке, Нахоg Симеон, Жииа, Змајеубиие и Деиа раяостии, као и најзначајније награде кроз које су препознате и признате и у интернационалним оквирима. ${ }^{1}$ Милена Марковић је и сценариста играних филмова Олега Новковића Суйра ујуйру (2007), Бели, бели свети (2009) и Ойаџбина (2016), као и документарног филма Руgарска оиерра (2006).

Када се сагледа цео опус Милене Марковић, и драмски и лирски, јасно је да није једноставно говорити о поезији Милене Марковић без осврта на њено драмско дело, као и о њеним драмама без увида у њену лирику, јер поетика њеног стваралаштва које се испољава кроз ова два израза, чини у извесном смислу целину повезану самосвојношћу и аутентичношћу њеног специфичног књижевног израза. Оно што свакако повезује ова два вида Милениног стваралачког израза, могло би се дефинисати као изворна лиричност постмодерног духа, а у њеном случају и као амбивалентни а истовремено плодотворни дијалог савременог урбаног мултимедијалног сензибилитета са дубинским токовима националне, и то првенствено усмене традиције. Иако стручна јавност Марковићеву у првом реду перципира као драмског писца који пише поезију, њена поезија посматрана као засебна целина, представља значајну чињеницу савремене српске поезије и недвосмислено потврђује њену изворну песничку вокацију. ${ }^{2}$ Зато ћемо се у овом раду осврнути на неколике

1 Милена Марковиће је за драмско стваралаштво добила специјалну награду у Бечу за набољу драму са екс-Ју простора, а добитница је и три Стеријине награде, те награда „Милош Црњански“, „Тодор Манојловић“ и „Борислав Михајловић Михиз“.

2 Милена Марковић: „Ја себе замишљам првенствено као песника, 
значајне тачке њене песничке поетике, које указују на већ поменуту аутентичност њеног песничког гласа, а то су: патриотски мотиви, дијалог са традицијом, нови модел женствености и песничко општење са мртвима.

Ако посматрамо њену поезију у контексту српске песничке традиције, онда она свакако припада линији српске наративне лирике која своје исходиште налази у модернизму и постмодернизму, а чине је песници нове лирске урбаности, рођени у градовима из времена соцреализма, махом шездесетих и седамдесетих година прошлог века, попут Милоша Комадине, Марије Кнежевић, Звонка Карановића, Срђана Ваљаревића, Драгане Младеновић. Оно што чини једну од специфичности песничког гласа Милене Марковић у односу на наведене песнике, јесте њен однос према традицији и патриотским темама, које се међу песницима урбане лирике третирају претежно у аутоиронијском кључу, и(ли) кроз негацију и дистанцу од ове традицијске линије. Милена Марковић пак гради амбивалентан и сложен однос са сопственом песничком традицијом, првенствено усменом, а патриотски мотиви у њеној поезији представљају јасно подсећање на то да постоје идентитет, језик, памћење и култура једног одређеног народа, на једном одређеном тлу и поред безнађа живота у транзицијској Србији, снова о животу у западном рају и личних фрустрација. У једној од својих најбољих песама, и парадигматској за ову тематску линију, „Ма-

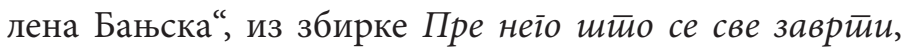
Милена управо спаја неспојиво кроз јасну емоцију и снажну, драматичну поенту: кренула сам у митировииу

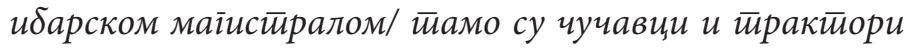

па и моје драме имају форму песме у смислу комплетности и заокружености. Оне имају своју метрику и ритам“. (Георгијев 2002) 
u gрвеће отиежало оg воћа/ и gевојчице са іолим йуйковима/ сииитла сам до косова одакле је моја мајка и/ юена мајка/ и сестира ми се тиамо родила а докйор је био иијан/вияела сам америчке војнике/ іузаии су а јеgан је носио/ бифокалне наочари.../.".

Патриотска поезија свакако представља ризично поље за сваког песника, јер управо се у овом тематском кругу, чак и код најбољих песника, може наићи на пригодност, претеривање, декоративност, патетику, или анахроно романтичарско подражавње традиционалних тема и мотива. ${ }^{4}$ Можда и због тога, патриотских тема међу песницима урбане наративне лирике готово и нема, осим кроз иронију, малодушност или одрицање, а реткост је да се неко од савремених песника, одраслих уз вредности америчке поп културе и неолиберални дух запада, као и Марковићева уосталом, позабави једном од најчешћих и најтежих тема наше песничке традиције, косовском. Већ у првим стиховима, која на први поглед делују као мирна констатација и набрајање призора поред пута, наилазимо на амбивалентне призоре Србије каква је данас, на почетку 21. века: Ибарска магистрала, чучавци, трактори, полуголе девојчице, али и дрвеће који обилато рађа и Косово, реч која наговештава да у песми није реч о

3 Наводи песама Милене Марковић у раду дати су према издањима: Милена Марковић: Песме, Београд: ЛОМ, 2012 и Милена Марковић: Песме за живе и мрйве, Београд: ЛОМ, 2014.

4 Образлажући изостављање највећег дела српске патриотске лирике из свог антологијског избора, Миодраг Павловић у предговору Анйолоїије срӣскої йеснишӣва бележи констатацију са којом се у целини можемо сагласити: „Патриотска поезија, која је традиционална и веома јака струја нашег песништва, била је најчешће претерана, романтична и пригодна пре Бојића, апстрактна (Дучић), декоративна (Ракић), или декламаторска у време Бојића“ (Павловић 1964: 122). 
још једном маниристичком приказу државе разорене транзицијом. Како уз ове социјалне одреднице стоји Косово? Сазнајемо да је то место песникињиног порекла по женској линији: „стигла сам до косова одакле је моја мајка и њена мајка и сестра ми се тамо родила а доктор је био пијан“, а свуда около „виселе су“ разне заставе које не значе ништа, само празне симболе нечега пролазног, а следи их гротескна слика највеће војне силе на свету - амерички војници који су „ниски и гузати“ и очигледно не личе на згодне маринце које је песникиња виђала по америчким филмовима. То је оно што је стварност, и тако на први поглед изгледа данас српско митско и заветно место. Нити су војници као у филмовима, нити је Косово као у песмама. Међутим, на том истом месту следи контрастна слика, попут уметнутог кадра који наговештава неки други свет и кратак предах од сурове и гротескне слике стварности: $a \bar{u} р a-$

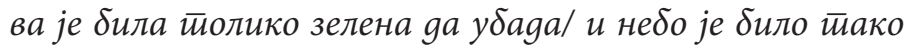
близу gа усйава/ слаgак сан на йусйом йољу.../. Песникиња наговештава да постоји још један дубљи слој значења који не може одмах да се уочи, а не може свако ни да га сагледа, али ако је у питању песник, и ако је његово породично порекло везано за Косово, а не само породично, него и културолошко, онда следе завршни стихови који у повишеном тону казују шта је све тамо песникињу сиииіло. А стигло је у моменту када је угледала натпис Бањска крај пута: забрујали су у њој стихови песме о Страхињићу Бану, забрујали су знани и незнани песници и стихови наше епике, митско осећање и сећање је оживело, и схватила је да се од тога не може и још важније, не треба побећи: и онда сам вияела знак са gесне ситране/ на юему је йисало банька/ и йу ме је сиичіла и баба и мајка и сестира и земльа/ и іроблье и ибар воgа и йу ме је стииіло/ и неће gа йустии/ и никаg неће gа 
иуусти и јер сам се сетиила/ усреg ноћи би се сетиила/ и ни-

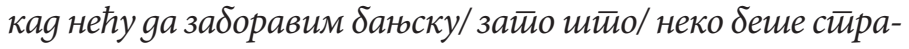
хиғићу бане/ беше бане у маленој/ банькој//.

Девојка одрасла у новобеоградским блоковима, уз рокенрол, стрипове и филмове, формирана уз урбане митове деведесетих година, у окружењу ратова, дроге, криминала, насилних смрти, осећа одједном то митско место и место порекла и идентитета са којима је одрастала, не знајући да постоје у њој. У њему су сада војници окупатора, и Косово је одједном нешто што не може и не треба да $\bar{u} y c \bar{u} u$, чега се не може одрећи и што се не заборавља. Један натпис крај пута одједном буди свест о томе да човек није изолована индивидуа, да појмови као сећање, идентитет, језик и култура нису пуке апстракције, већ оно без чега нико није ни целовит ни цео, а поготово песник. То је уосталом, али не као последње, самосвест и свест о љубави упркос свему, љубави за оно што човек јесте, упркос бесу, иронији, страдању, смеху, горчини и јаду због онога како данас изгледа место њеног порекла. То је љубав без идеализовања и сентиментализма. Кроз песму „Малена бањска“, песникиња градацијски појачава почетну емотивну интонацију, која креће од равнодушног набрајања, преко ироније, до поетичних слика природе, да би у снажној поенти довела до катарзичног врхунца, слично као у њеним драмама. Снага песникињиног изворног импулса и чистог доживљаја, потенцирана је и сталним контрастирањем суморних и чистих слика, иронијом, хумором и гротескним сликама („гузати војници“, „бифокалне наочаре“ уз „сладак сан на пустом пољу“), да би у завршној слици узрасла до готово свечаног тона, који завршава подражавањем стихова чувене песме о Страхинићу Бану, али у њеној интерпретацији без изворног епског (неко уместио нешико) десетерца, у завршна два стиха разломљеног, попут ритма успаванки. Јер песничка имагинација зна да ово није време јуначког епског дестерца, него чувања стиха у 
сећању, у сну, у колективном памћењу. Тако се патриотизам Милене Марковић не огледа у сентименталном и патетичном поносу што припада народу коме припада, нити у борбеним покличима или елегичном јадиковању, већ у љубави према њему упркос свему што види, а то што види није за понос и она то зна. Ту је њена специфичност у односу на генерацијски и стилски блиске песнике, који такође луцидно сагледавају све ужасе живота у трауматизованој држави, али они се заустављају на тој позицији или се у аутоиронијском кључу баве појмовима као што су порекло, идентитет, традиција. Марковићева види све то, али и прихвата у потпуности, јер схвата да се од себе, као ни од поворке која јој претходи у низу баба, мама, тетка, сестра, не може и не сме побећи, а да се не изгуби и део себе. Ту је њена могућа снага трајања и настављања, баш као и у стиховима који изненада почињу да брује у свакоме ко их се свесно не одрекне, али без затварања очију пред свим тамним, мучним, застрашујућим, а на моменте светлим и блиставим моментима које прате такав избор.

Када је реч о патриотским мотивима у песмама Милене Марковић, не треба губити из вида да је она песникиња интимистичке поезије исповедног тона, да су у њеним стиховима мотиви дубоко лични и обојени интимним доживљајем света. Песникиња не распевава поједине теме, њене збирке нису тематски циклуси у класичном схватању тог појма. Оне су фрагментарне, као и њене драме уосталом: фрагменти слика, или тачније кадрови, ${ }^{5}$ који стварају једну целовиту слику од изломљених делова. У једном другачијем кадрирању, кроз стихове песме „Лаку ноћ синови моји“, из збирке Пре неі̄о шито све йочне gа се вриии Марковићева ће на другачији начин исказати љубав за свој прља-

5 Ово свакако није неочекивано, ако имамо у виду да је Марковићева и сценариста играних филмова, а мултимедијална свест модерних стваралаца формирана је, између осталог, и на свеприсутној филмској естетици. 
ви и ружни град, за своје место рођења, као и за младе бесне момке које називају хулиганима, убацивши у завршне стихове и Гаврила Принципа, цитирајући га: синови моји не рушитие/ іраg он ће иреживетии и вас и юих и юихове/ и

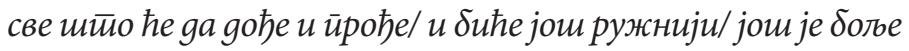
gа не мрзите неіо/ чекајие/ и нишита нема смисла знам и/

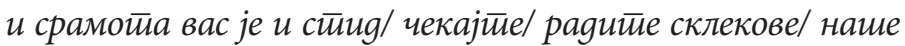

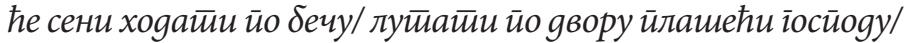
чекајйе/ лаку ноћ синови моји//. Несвакидашњим подвигом Гаврила Принципа и његових сабораца Милена Марковић се бави у драми Змајеубице, ,јуначком кабареу“ како га жанровски одређује у уводу, издижући његов чин изнад плитких идеолошких и политичких конотација, доводећи га у раван заборављене људске способности свесног саможртвовања за добро других. ${ }^{6}$

Везаност за сопствено порекло, земљу и идентитет је нешто што песникиња прихвата без остатка и улепшавања, али истовремено схвата апсурдност и безизлазност своје позиције, што се јасно сагледава у горко хуморним, самоироничним, гротескним, а ипак љубавним стиховима песме „Дупе и крофна“: ми се разликујемо/ моіу ја йеঠе gа волим/ али разликујемо се/ каgа би земла била $y^{* * * * * / \bar{u} а ~ \delta u ~}$

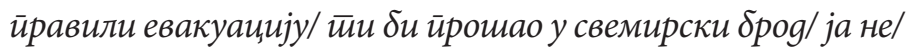

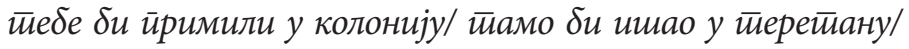

6 „И срећна је чињеница што је Милена Марковић ту способност и ту жељу препознала и што их сматра суштином тог младог бића чији је кратки живот протекао у суровом самоодрицању и општој прикраћености („и ја бих можда хтео да направим сина / и ја бих можда хтео да угледам море / и ја бих можда хтео песму написати / али ја сам из блата и ја ћу пуцати“). И зато из њеног Принципа, поред невероватне снаге која му је, поред осталог, за читаве две године, у односу на животе његових другова, само продужила казаматске патње, избија потресна туга, она коју осећа само неправдом уцвељено дете.“ (Миочиновић 2014) 


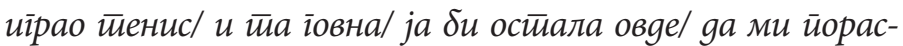

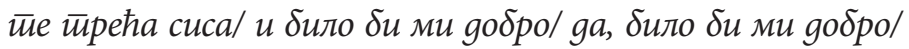
gобро сииаро суние се іуши/ а мени је gобро...//. Љубав је честа тема у песмама Марковићеве, а песникиња се и према једној од најстаријих и најтананијих песничких тема односи беспоштедно искрено, огољеним уличним речником, а дубоку емоцију одева у наоко баналне, црнохуморне и гротескне слике. Оваквим необичним песничким поступком, она парадоксално успева да сачува чистоту емоције од свих наноса гротескне (препостављене) стварности, вулгарних речи, чак и од туговања због неостварене љубави. Кроз наносе слика, наоко неспојивих са љубавним осећањем, песникиња постиже појачани почетни доживљај и у ефектној поенти, разоткрива нежну природу испод самоиронијских исказа: ја би јела коренье/ са gобрим стиарим сунцем у йозаяини/ и бубашвабама муйираним/ и йацовима са очначима/ јеgина добра стивар/ ийо би наиравили клонове/ ӣреgивне тивоје//. Поигравањем са апокалиптичним визијама и футуристичким мотивима преузетим из поп културе, песникиња делимично оцртава и генерацијски став оних који су одрастали деведесетих година претходног века, а сада су на прагу зрелости: ради се о филозофској помирености са сваким усудом који би могао доћи из непредвидивог, а најчешће грубог и човеку ненаклоњеног спољњег света и спремности да се суочи са свиме што следи, јер, показало се већ, живот увек нађе начина да се настави. Ипак, до оваквих увида песникиња је долазила посредно и постепено, јер доминантни тон њене поезије је био и остао интимистичко разматрање, набрајање и посматрање породичних тема, судар личних и колективних митова, стална подељеност између жеље да се одбаци све што представља живот у трауматизованој Србији и истовремене дубинске везаности за тај простор и све што он представља за песника до његовог потпуног прихватања. 
Кроз наведене стихове се може уочити још једна од специфичности поетике Милене Марковић, а назвали бисмо је нови модел женствености који претпоставља истовремено рушење, изградњу и реинтерпретацију познатих женских архетипских образаца, попут улога ћерке, сестре, девице, мајке, љубавнице. Нови модел женствености би тако подразумевао модификоване или обесмишљене архетипове женствености, а у драмама Милене Марковић се ови обрасци јављају као иронијски, амбивалентни, гротескни и карневализован ликови попут улога „Мајка, курва што је оставила дете“ и „Удовица, која је била у великом свету“ у Наxоgy Симеону, или Девојчица, Лака женска, Психолог, Заробљеница и Медицинска сестра које се све зову Рупица у Шинама, док поигравање са традиционалним митским моделом виле налазимо у драми Шума блистиа где се женски ликови зову Плава, Црна и Смеђа. Међутим, вишезначност женских ликова у њеним драмама не значи и традиционално претпостављен извор женске моћи, „већ извор угрожености. Све традиционалне представе о граничној природи жене и моћи женских демона, бивају у драми Милене Марковић суштински десемантизоване“ (Пешикан Љуштановић 2008: 13).

У песмама Милене Марковић, за које је тешко говорити о лирском субјекту, јер су све испеване исповедним тоном, овако маркиран нови модел женствености садржи у себи све традиционалне обрасце који је везују за породицу, место порекла, град у коме живи, а истовремено и њихову потпуну деконструкцију која доноси нове, модификоване обрасце који једновремено постоје у жени и појављују се као низови нових улога. Традиционалне обрасце који представљају изворни модел, жена више није у могућности да реализује. Она је несавршена мајка: и роgила сам gетие рано/ и gојила 
сам gетете gве іооине/ и он није никако йочиғао gа йрича/ и стиално је тирчао и итрчао, њено дете је млаgунаи, за кога је можда и боље да је не памти: а шйа са мојим

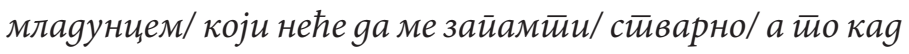
размислиш/ уоитите није тоша сиивар//. Она је и несигурна девојка која ниже љубавне промашаје, жена која се плаши старења: стиарим/ и нема више тиајне/ све знам шйа ми ко мисли/ осмех имам на лииу он је као/ срча на кайији и која моли за љубав, пије, пуши, псује и плаче: шикам /и јеgем салайу/ иричам иеелебоном/кажи ми

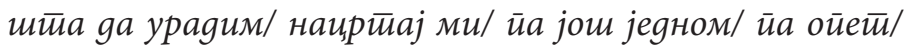
не туити се шито не йамитим нишйа/ йонови/ насмеј се из сииомака онако/ узимај йола моје ииіаретие/ јер сам

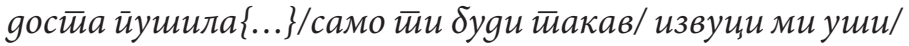
наљуити се/ вичи/ не јавтај се неко време/ йа онgа објасни шито ниси/ само никаg никаg/ молим тие/ молим тие/ никаg никаg/ немој туубави/ немој gа gиінеш руке/ оg мене//. Овакав нови модел женствености у истој мери одудара и од традиционалног патријархалног модела, колико и од феминистичких визија моћне, ослобођене женствености, он настаје кроз хаотичне сударе претпостављених и стварних образаца и формира се у колебљивој равнотежи спољњих, друштвених и дубоко личних, архетипских чинилаца. Он је свакако и дубоко индивидуалан одговор сваке поједине жене у одређеној животној ситуацији у конкретном времену и простору на изазов изградње целовите женске личности, разапете између жељеног и могућег. Утолико пре можемо говорити о низу нових образаца женствености који се усвајају, одбацују и мењају убрзано, али оно што остаје њихов темељ и полазна тачка остаје непромењено, а то је низ жена који им претходи, у односу на које се нови модел и ствара. Тога је дубоко свесна и песникиња, помирена са својом женском природом, 
емотивном, бунтовном, заиграном, у потрази за љубављу. Због тога у својим песмама заузима позицију посматрача света, али и сопственог живота и својих избора, који се као фрагменти слика смењују са кратким, али дубоко лирским исказима.

Специфичан је и однос према смрти у поезији Милене Марковић, која је уз љубав, један од најчешћих мотива њених песама. Међутим, песникиња се не бави смрћу као филозофским питањем, тачније смрт као апстрактни појам готово и да не постоји у њеним песмама, али зато су мртви стално присутни, потпуно равноправно са онима који су живи. Између живих и мртвих не постоје уобичајене границе, песникиња води разговоре са њима, без патетике говора у онострано или страха, свакодневним колоквијалним говором: ge cu ми саg gруже/ каg слушам музику/ јеси мртиав/ шито си ми мртиав бре/ каg ми йребаш саg/ каg слушам музику/ ийо си ми мрйав каg ми йребаш саg/ ...ено их живе/

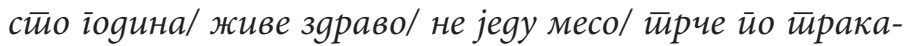

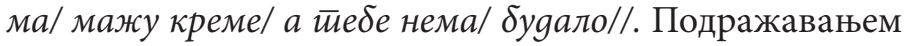
тужбалице, понављањима и набрајањем песникиња упућује на традиционалан однос према мртвима, али и на своју везу са усменом традицијом, лирском, или још прецизније, женском, онако како је Вук назвао и која се из најдубљих временских слојева одржала живом управо преко женске песничке линије. ${ }^{7}$ Мртви су

7 У своје драмске текстове, Марковићева уводи и елементе бајки, митску грађу, бајалице: „С друге стране, својим лирским брутализмом, моћним, застрашујућим сликама и снажним емотивним избојима које постиже користећи бајку као код Милена Марковић ефектно сведочи о неугаслом естетском и значењском витализму овог жанра и о томе да бајку, као особени 'дивљи жанр', култура не може поновити у њеној исконској једноставности, али је не може ни заборавити" (Пешикан Љуштановић 2010: 589). 
сасвим близу, ближи и од многих који су привидно живи, а управо њено обраћање свакодневним говором, оним којим су увек разговарали, јесте једино и могуће

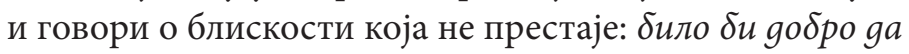
оgемо неїде чамцем/ маgа ја више нисам онако зіоgна/ а не би били ни ви/ gа нистее на йример мрйви/...знам gа би мислили на мене/ можgа и више неі̄о/ шито ја мистим на вас/ затио тито би били боли тьуди/ неіо шито сам ja/ga сйе на йример/живи//. Њена последња збирка се зове Песме за живе и мрйве, што асоцира на традиционално хришћанско схватање заједнице живих и мртвих и обичај паљења свећа, али као и у њеним драмама, однос са традицијом нити је једноставан нити једнозначан и указује на динамичну и амбивалентну везу. ${ }^{8}$ Њен дијалог са традицијом, у првом реду усменом, креће се од реинтерпретације и реинтеграције, преко алузија и певања на нароgну у сонговима њених драма, до деконструкције и обесмишљавања коју постиже формулативним понављањима као у песми „Реко моја речице“

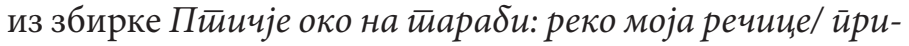
ми мене мајчице/ реко моја речице/ оg сумрака румена/ a оg јуйра блистиава/ а у йоgне ойасна/ реко моја речице//. Песникиња понавља рефрен песме узимајући речник усмене лирике да би додатно нагласила апсурдност савременог света и различитих облика његове свести у односу на митско време које призива у песми, али га истовремено и обесмишљава, јер нема илузија о мо-

8 Однос Милене Марковић према традицији, можда најбоље илуструје белешка другог песника, Миодрага Павловића: „Чудна психолошка двосмерност опседа оне који пишу: кад сматрају да се могу и морају одвојити од традиције, осетиће да су крвљу и мишљу везани за њу, а кад хоће да јој се повинују и да претерају у поштовању, виде колико су њихов живот и мисао нешто друго, одвојено од свега што им је претходило“ (Павловић 1958: 10). 
гућности повратка у изворно митско стање. На тај начин наглашава и апсурдност сваког могућег коначног става који савремени човек може поуздано да усвоји и задржи. Међутим, једино поуздано и сигурно у овом свету јесу љубав и смрт, то су основне тачке ослонца у вишезначном и дубоко интимном поетском свету Милене Марковић, а љубав засигурно прелази границе смрти: каg се зайлеgам gалеко/ вияим мене и йебе/ као мирне ситарие:/... ја желим gа овем иррва/ али знам gа

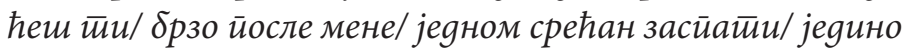

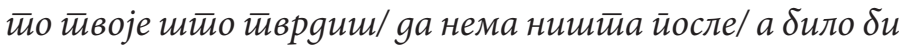
лейо/ gа живимо оиети и оиетй/ и gа се срећемо/ замисли/ йи возиш кола а ја стиоитрам/ уђем/ иолілеgамо се/ и йо

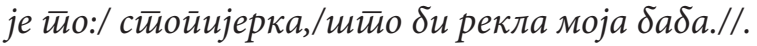

Стари патријархални обрасци су разорени, оно што су биле њена баба, мама, тетка, више не функционише у свету сталних и хаотичних промена. Свет је изломљен и фрагментизован, а живот пролази док га посматрамо као у кадру. Ипак, оно што гради цео свет песникиње и држи га на окупу јесте љубав, и чиста непатворена емотивност, која постаје основни образац за преживљавање и залог трајања. У свету у коме човек губи све тачке ослонца, једини ослонац јсте сведочење о сопственом постојању. Без сентимента, сурово искрена, самосвесна и прочишћена од интелектуализовања, укорењена у традицију и модерна, аутентичног језика, створеног поигравањем са усменим обрасцима, урбаним сленгом, дијалектизмима и наративним исказима, поезија Милене Марковић представља озбиљан и незаобилазни песнички глас новије српске лирике. 


\section{Извори и литература}

Georgijev, Slobodan. „Godine idiotizma (intervju sa Milenom Marković)“. Vreme 621 (2002). Veb: 07.05.2018.

Marković, Milena: Pesme. Beograd: LOM, 2012a. Štampano.

Marković, Milena: Drame. Beograd: LOM, 2012b. Štampano.

Marković, Milena: Pesme za žive i mrtve. Beograd: LOM, 2014. Štampano.

Miočinović, Mirjana. „...Izvesna je samo smrt ( o drami Zmajeubice Milene Marković)“. Vreme

1223. (2014). Veb: 04.05. 2018.

Пешикан Љуштановић, Љиљана. „Вила у супи“. Шума бли$c \bar{u} a$ (програм представе).

Београд: Атеље 212 (2008/09): 9 -13. Штампано.

Пешикан Љуштановић, Љиљана. „Бајка као културни код у 'Броду за лутке' Милене

Марковић“. Кюижевности и кулитура 39/2 (2010): 587-601. Штампано.

Павловић, Миодраг. Рокови йоезије. Београд: СКЗ, 1958. Штампано.

Павловић, Миодраг. Анйолоіија срӣской иееснишӣва (XI go $X X$ век).Нови Сад: Издавачки центар Матице српске, 2010. Штампано.

Živanović, Branislav. „Između tarabe i konopca“. Zlatna greda 103/104 (2010): 78-79.

Štampano. 
Maja Radonić

POETRY FOR LIVING AND DEATH

(About the poems by Milena Marković)

\section{Summary}

The poetry of contemporary drama writer, screenwriter and poetess Milena Marković (1974) is relatively small among the researchers of her work in relation to dramatic opus. However, this modern and powerful poetic voice of recent Serbian poetry brings at first glance a hidden but essentially authentic connection with its own poetic tradition. This paper points to the specificity and self-assurance of poetic poetics of Milena Marković, by which the poetess of narrative statements, confessional tone and everyday language, deprived of intellectualization, attains high lyricism and persuasiveness of true poetry.

Key words: Milena Marković, poetry, poetics, narrativeness, tradition. 